\title{
Fan Ngin Tong Ngin Tjit Jong - The Assimilation Face of Grassroot of Chinese Ethnic in Bangka Island, Indonesia
}

\author{
Ibrahim Ibrahim ${ }^{1 *}$, Rendy Rendy ${ }^{1}$, Sujadmi Sujadmi ${ }^{2}$, Putra Pratama Saputra ${ }^{2}$, and \\ Luna Febriani ${ }^{2}$ \\ ${ }^{1}$ Department of Political Science, Universitas Bangka Belitung, Gg. IV No.1, Balun Ijuk, \\ Balunijuk 33172, Bangka, Indonesia. \\ ${ }^{2}$ Department of Sociology, Universitas Bangka Belitung, Gg. IV No.1, Balun Ijuk, Balunijuk 33172, \\ Bangka, Indonesia.
}

\begin{abstract}
Chinese ethnic in Bangka Island has been there since the colonialism and has become part of tin mining history on the island. It is no wonder that the acculturation has stated for a long time ago especially in the grass root society. This study found out how is Chinese assimilation in this area using the qualitative approach. Based on the data from interviews and observations on the field, the writer found out that Chinese assimilation on the island formed a unity identity without losing their own identity. Tong Ngin Fan Ngin Tjit Tjong which means Chinese and Native, has become the grass roots' principle and social bond among them. Since the reformation in 1998, this broadens the relation from social into electoral politics. However, the spirit of acculturation in the grass roots must be kept that it doesn't appear to the surface. The celebration of Chinese identity recognition must be done naturally so as not to cause antipathy. The tolerance that has been practiced so far at the grassroots must be strengthened so that when conflicts of elite interests occur, relations at the grassroots level are not affected.
\end{abstract}

Keywords: Acculturation, Chinese assimilation, harmony of the Chinese and the native, high tolerance, unity identity.

\section{Introduction}

The history of the existence of ethnic Chinese in Bangka Belitung, Indonesia is almost as old as the history of tin mining. The history of Chinese migration to this area is basically the history of tin mining because, at that time, workers from China were considered to have mastered tin mining technology as they had long done in their country [1]. The wave of Chinese migration to Bangka Island itself was estimated in the 17th and 18th centuries, although by Reid [2-4], it was mentioned that in fact, this ethnic contact in this region had been going well before the mining era arrived.

It is interesting to study the presence of Chinese ethnic on the island for Bangka Belitung islands are the area which is known for harmony by the population of them $25 \%$

\footnotetext{
*Corresponding author: $\underline{\text { iim_babel@yahoo.com }}$
} 
from the total population about $1.4 \times 10^{6}$. The harmony of the Chinese and the native is known with the concept of Fan Ngin Tong Ngin Tjit Tjong which means Chinese and native are equal. The social configuration between Chinese and Native in this area is quite different from other areas that have a high tolerance.

However, as two different identities, there is no friction in this area. There is group identity, but on some boundaries, the identity melts into one. This study will figure out how the people maintain the difference and on which boundaries that identity strengthens one another. As the place is well known for the mining of Chinese migration history, this study will find out how to build social relations among two different identities.

\section{Research method}

This paper was obtained from research with a descriptive qualitative model, which illustrates how the face of assimilation of China and local residents on Bangka Island. Data collection techniques used are observation and interview models. Informants were determined based on a purposive sampling scheme, namely decision making based on certain considerations; in this case, community leaders from ethnic Chinese circles and figures from among non-Chinese local residents. The locus of research is Ketap, Lampur, and Batu Deer villages. These three villages are known as areas inhabited by Chinese ethnic and local people who live in harmony. Ketap Village is located in West Bangka Regency, Lampur Village in Central Bangka Regency, and Batu Rusa Village in Bangka Regency.

\section{Finding and discussion}

\subsection{Bangka Chinese}

The term Bangka Chinese originally refers to the people or comunitiy of Chinese in Bangka. This term refers to the identity that differentiates the identity of Bangka Chinese with the Chinese in another are. The difference is not merely about given such as place of origin, skin colour, and ethnic sub compared with the other area, but this refers to the certain colour of the Bangka Chinese and another Chinese. In the smaller dimension, it is even a presence term that differentiates Bangka Chinese and Belitung Chinese.

Bangka Chinese came along with the process of tin exploitation in this area in the 17th and 18th centuries [5]. The history of tin mining is the history of Chinese migration that entered through Singapore and was coordinated by bosses called by the term Tiko $[6,7]$. Bangka Chinese came as huagong, namely as a coolie who worked in tin mines [8, 9], which at that time was called the trench $[10,11]$. Thus, in terms of arrival motives, even Bangka Chinese was different from other regions who came as traders. The motives for these arrivals form a different culture, for example, regarding the pattern of settlements in which Bangka China resides more in areas that are rich in tin resources and were part of the mining area in the past.

When there was political upheaval in China, and there were differences in treatment between Chinese in China and Chinese outside China [12-14], it was difficult for Chinese migrants in Bangka to return to their regions. This is the reason why not a few Bangka Chinese mate with local residents and form attractive hybrid identities. At the same time, the confluence of two different identities forms a broader pattern of relations, marked by the large number of Chinese who embrace local religions so that it is socio-culturally difficult to distinguish from local residents. As Ahyan said, "We don't want to be called Chinese anymore."

Quantitatively, the population census states that the Chinese ethnic in Bangka has the largest percentage in Indonesia, which is $8.05 \%$, although this figure will actually differ in 
real terms with the predicted number greater [15]. The largest Chinese population is in Bangka Regency, also considering that this area has a total population of the five regions on Bangka Island. The use of the term Bangka Chinese thus refers to certain identities exhibited by China in this area.

\subsection{Assimilation of acculturation characterization}

During the New Order period (1966 to 1998), the Indonesian government's style was characterized by a total assimilation project in which ethnic Chinese had to abandon all their traditions and culture and adapt to the local population [16-22]. It is not surprising that during the New Order period, assimilation was marked by the loss of Chinese identity and the obligation to adapt [23-25].

Interestingly, on the island of Bangka, Chinese is indeed included in one of the identity clusters targeted by assimilation, but in fact, their identities have never really dissolved and disappeared. One informant, Ahyan, said that although the New Order era was prohibited from carrying out ethnic Chinese rituals, they still practiced it secretly.

Demographically, Chinese ethnic remain in groups in areas where they have lived for a long time, both in villages and in cities. In villages, they live in trenches and mine-rich areas, while in cities, they live in market areas and control trade. Chinese remains Chinese, and they continue to form their own identity.

Even in one of the villages, the writer found a unique view, namely a pig farm located in an area with local residents. There is no conflict with regard to pigs, which actually blend in like other local residents even though the majority Muslim population does not consume the meat. Aon, one of the Chinese leaders in Ketap, said that there were almost no complaints about pig livestock mingling with residential areas. This is interesting because the fact is found that tolerance is treated in grassroots chambers.

Meanwhile, in one of the villages that were also the object of research, the writer found a unique blend of daily life with the discovery of pesantren in an area that is not bounded directly by Chinese settlements. In Mentok, West Bangka itself, one of the unique views that are often used as a tourist icon is the establishment of a mosque adjacent to the temple, a place of worship for Chinese citizens. The same thing is found in one of the areas on Sungai Liat, Bangka Regency, which is colored with mosques and temples facing each other.

The condition above depicts the real social relation between the Chinese and local people in Bangka island that has done acculturation since a long time ago. Sin Pon, one of the informan in Bangka, told us how they maintain tolerance by socializing without differentiating one another. The acculturation itself is the mixture of two different cultures, in which they form a new culture without losing their own identity culture or identity.

Social relation practice in Bangka Island actually is assimilation with the character of acculturation. On the grassroot level, tolerance and appreciating differences have been established since many times ago. Ce Li, one of our informants, said, "If we go, our Malay neighbour will take care of our house. If someone has a pilgrimage, we come. We visit one another during the religious celebration". Aji, another informant, told that tolerance has taught hereditary and has become a tradition.

\subsection{Broaden relation arena}

Since reformation replaced new order in 1998, basic transformation in the social politic of Chinese ethnic is the orientation of the politic social ethnic. At least there has been a shift towards social life, among others is the increase of re-claiming of identity, which is marked by an increase in the traditions of ancestors who, once lost, are now practiced again. The Chinese who could not celebrate Confucian holidays openly had room to celebrate. 
Barongsai traditions, religious celebrations, to the recognition of Confucian beliefs by the state became a new phenomenon of ethnic Chinese social life.

Meanwhile, in politics, there was an increase of ethnic Chinese participation, including involvement in the candidacy of Legislative Members, becoming regional heads or deputy regional heads, and even the increasing political interest at the grassroots level. Many villages are now led by Chinese, both in villages that are inhabited by ethnic Chinese majority, as well as those dominated by local residents.

This expansion in the arena of relations has only increased since the reforms began. Various regulations that limit the political life of China have been reviewed, and this ethnic group has gotten their part with other residents. A very different condition compared to the assimilation period during the New Order. Ahok is one example of an ethnic Chinese revival in Bangka Belitung, followed by his younger brother, Basuri Tjahaya Purnama. At present, there are two regional heads currently serving from China, namely Markus in West Bangka and Isyak Meirobie in Belitung. In the Indonesian Parliament, there is the name of Rudianto Tjen, Telly Gozalie, Bahar Buasan, also the name Bambang Pattijaya. The increase in ethnic Chinese participation in a wider space indicates that this ethnic group is placed at least in line with other ethnic groups. The expansion of the arena has also increased in the organizational sector, where many social organizations are now being held by ethnic Chinese.

\subsection{Guessing the assimilation direction}

There is an interesting question then that should be asked regarding the face of Chinese ethnic assimilation at the grassroots on Bangka Island: How is the direction of this ethnic assimilation in the future? First, the author believes that the rise of ethnic Chinese in their relations with the social and political world will eventually be aligned with other ethnic groups and will be widely accepted as part of the consequences of democracy and state citizenship in Indonesia. Of course, with an important note that local residents who are not from Chinese circles realize that pluralism and diversity are basic commitments that must be maintained. That is, although so far there are no problems with the building of pluralism on Bangka Island, it still needs to be reminded to the local population to assume that the existence and expansion of ethnic Chinese social relations are commonplace and is not an attempt to dominate the minority over the majority.

Second, it is important to note that opportunities for identity conflicts will arise and develop when identity recognition is over-celebrated. That is, the ethnic Chinese need to position the process of metamorphosis and normative, gentle, and not an excessive acceptance of identity acceptability [26]. Because of the writer's concern, as has been confirmed in the study of Ibrahim [27] that excessive celebrations of identity in the reform era have the potential to cause antipathy [28, 29], which will not be constructive for tolerance and difference.

Third, the cultural acculturation in the grass root level must always be strengthened. The elite is often built a different perception, and because of the conflict of interest, get into the grass roots. However, if the grass roots are solid and committed to keeping the difference, the chance of a conflict of identity will not appear [30-32]. So the current practice of tolerance and social relations at the grassroots must continue to be strengthened, a condition that explains why when the Anti-China riots in Jakarta and other cities broke out in 1998, Bangka Belitung did not participate. 


\section{Conclusion}

The principle of Tong Ngin Fan Ngin Tjit Jong is a basic principle that puts the social relation of Chinese ethnic and native during a long history in Bangka that has never had a serious conflict. Since a long time ago, the process of assimilation in Bangka has already got acculturation character, a situation when the Chinese ethnic and the native build relation and new culture, but they do not lose their identity. Bangka Chinese still become Chinese with a contribution to Bangka and form pluralism face. This study found that at the grass root level, it is more dominant of the acculturation with tradition and culture of each ethnic that still exists. Later, the expansion of the arena of social relations between China and the local population had come into the electoral political dimension marked by increasing the role of ethnic Chinese in the formal political world. This study finally guessed that there are three important things that must be discussed together in the future, namely the importance of continuing to strengthen the spirit of tolerance at the grassroots in order to remain a strong social adhesive capital, the need to encourage celebrations of identity recognition in the reform era in moderation, so that does not cause antipathy. Acculturation at the grassroots must be strengthened so that when there are elite conflicts going forward, cracks at the grassroots level can be avoided.

\section{References}

1. M.F.S. Heidhues, Timah Bangka dan Lada Mentok, Peran Masyarakat Tionghoa dalam Pembangunan Pulau Bangka Abad XVIII s/d Abad XX. [Bangka Tin and Mentok Pepper: Chinese Settlement on an Indonesian Island], Jakarta: Yayasan Nabil (2008), p. 2-15. [in Bahasa Indonesia]. https://www.worldcat.org/title/timah-bangkadan-lada-mentok-peran-masyarakat-tionghoa-dalam-pembangunan-pulau-bangkaabad-xviii-sd-abad-xx/oclc/697276903

2. A. Reid, Chinese on The Mining Frontier in Southeast Asia in Chinese Circulations, Capital, Commodities, and Networks in Southeast Asia. E. Tagliacozzo, W-C. Chang (Eds). Durham and London: Duke University Press. (2011). p. 21-36. http://www.oapen.org/download?type=document $\&$ docid $=1004298$

3. R. Kavin, Jurnal Administrasi Pemerintahan Daerah 8,2:75-92(2013). [in Bahasa Indonesia]. http://ejournal.ipdn.ac.id/JAPD/article/view/84/40

4. M.S. Satya, B. Maftuh, Jurnal Pendidikan Ilmu Sosial, 25,1:10-23(2016). [in Bahasa Indonesia]. https://ejournal.upi.edu/index.php/jpis/article/view/3667/2619

5. C.A. Coppel, Indonesian Chinese in Crisis. Kuala Lumpur: Oxford University Press (1983). p. 4. https://www.nlb.gov.sg/biblio/2945752

6. C.A. Trocki, Journal of Chinese Overseas, 1,2:147-168(2005). https://brill.com/view/journals/jco/1/2/article-p147_2.xml

7. S. Sujitno, Dampak Kehadiran Timah Indonesia Sepanjang Sejarah. [The Impact of Indonesia's Tin Presence Throughout History], Jakarta: Cempaka Publishing(2007), p.64. [in Bahasa Indonesia].https://catalogue.nla.gov.au/Record/7245124

8. W. Gungwu, Asian Ethnicity, 10,3:201-216(2009). https://www.tandfonline.com/doi/abs/10.1080/14631360903189674

9. Rusnaini, Jurnal Penelitian Humaniora, 2006:99-114(2006). [in Bahasa Indonesia]. https://www.scribdcom/doc/46876906/Kehidupan-Sosial-Budaya-Etnis-Cina-DiPulau-Bangka

10. W.T. Peng, The Origins of Chinese Kongsi, Selangor: Pelanduk Publications (1994). p. 47. https://www.amazon.com/Origins-Chinese-Kongsi-Wang-Peng/dp/9679784495 
11. I. Santosa, Peranakan Tionghoa di Nusantara, Catatan Perjalanan dari Barat ke Timur, [Chinese in the Archipelago, Travel Records from West to East], Jakarta: Penerbit Buku Kompas (2012). p. 239. [in Bahasa Indonesia]. https://catalogue.nla.gov.au/Record/5978513

12. D.E. Willmott, The Chinese of Semarang: A Changing Minority in Indonesia. Itacha dan London: Cornell University Press (1960). p. 23.

https://www.researchgate.net/publication/273031903_Donald_Earl_Willmott_The_Ch inese of Semarang_A Changing_Minority in_Indonesia_Cornell_University_Press Ithaca New York 1960_xii 374_pp 6

13. A. Reid, Asian Ethnicity, 10,3:285-296(2009). https://www.tandfonline.com/doi/abs/10.1080/14631360903189666

14. C.K. Tong, Between a Rock and a Hard Place: The Chinese in Indonesia dalam Identity and Ethnic Relations in Southeast Asia, Dordrecht: Springer(2010). p. 111145. https://link.springer.com/chapter/10.1007/978-90-481-8909-0_5

15. Ibrahim. GSTF Journal of Law and Social Sciences (JLSS), 5,1:1-7(2016). http://dl6.globalstf.org/index.php/jlss/article/view/1703/1738

16. A. Budiman, Rethinking Ethnicity and Nationalism: Anti-Chinese and Anti-Australian Sentiment in Indonesia. In: Indonesia, The Uncertain Transition, D. Kingsbury, A. Budiman (Eds). Adelaide: Crawford House Publishing. (2001). p. 274. http://dro.deakin.edu.au/view/DU:30010052

17. L. Suryadinata, Ethnic Chinses in Southeast Asia: Overseas Chinese, Chinese Overseas, or Southeast Asians? In: Ethnic Chinese and Southeast Asians, L.

Suryadinata (Ed). Pasir Panjang dan New South Wales: Institute of Southeast Asian Studies dan allen \& Unwin (1997). p. 11-13.

https://bookshop.iseas.edu.sg/publication/195

18. S. Turner, P. Allen, Asia Pacific Viewpoint, 48,1:112-127(2007). https://onlinelibrary.wiley.com/doi/abs/10.1111/j.1467-8373.2007.00334.x

19. G.V. Klinken. Ethnicity in Indonesia, In: Ethnicity in Asia, C. Mackerras (Ed). London dan New York: Routledge Curzon (2003). p. 69-70. https://papers.ssrn.com/sol3/papers.cfm?abstract_id=1127126

20. J. Herlijanto, The May 1998 Riots and The Emergence of Chinese Indonesians: Social Movements in The Pos-Soeharto Era, Paper presented at Konferensi International Asosiasi Sejarahrawan Asia (IAHA). 6-10 Desember 2004, (Academia Sinica Taipei, Taiwan, 2004. p. 64-80.

http://citeseerx.ist.psu.edu/viewdoc/download?doi=10.1.1.542.4155\&rep=rep1\&type= pdf

21. F.V. Aguila, Citizenship, Inheritance, and the Indigenizing of 'Orang Chinese' in Indonesia Positions, Durham: Duke University Press (2001). p. 504. https://www.researchgate.net/publication/31042694_Citizenship_Inheritance and the Indigenizing of Orang_Chinese in_Indonesia

22. M. Itoh, Peranakanization, Indonesianization, and Cultural Citizenship Among The Ethnic Chinese in An Indonesian Town: The Case of Makassar. Urbanization and Formation of The Ethnicity in Southeast Asia, editor Toh Goda. Quezon City : New Day Publisher (2009). p. 176-192. https://www.worldcat.org/title/urbanization-andformation-of-ethnicity-in-southeast-asia/oclc/679317216

23. C. Chua, Journal of Contemporary Asia, 34,4:465-479(2006). https://www.researchgate.net/publication/249041619_Defining_Indonesian_Chinesen ess_under_the_New_Order 
24. L. Freedman, Political Participation and Ethnic Minorities, Chinese Overseas in Malaysia, Indonesia, and The United States. New York dan London: Routledge (2000). p. 3. https://www.amazon.com/Political-Participation-Ethnic-MinoritiesIndonesia/dp/0415924464

25. R. Thaniago, Disciplining Tionghoa: Critical Discourse Analysis of News Media During Indonesia's New Order. [Thesis], Media and Communication Studies, University Lund, Sweden (2017).

http://lup.lub.lu.se/luur/download?func=downloadFile\&recordOId=8916918\&fileOId $=8916922$

26. T.J. Lan, Jurnal Masyarakat Indonesia, 43,2:197-206(2017). [in Bahasa Indonesia]. http://jmi.ipsk.lipi.go.id/index.php/jmiipsk/article/download/738/509

27. Ibrahim, Bisnis, Kekuasaan, dan Identitas (Studi terhadap Politik Identitas Etnis Tionghoa di Bangka Belitung Pasca Order Baru), [Business, Power, And Identity]. [Ph.D Thesis], Political Science, Universitas Gadjah Mada, Yogyakarta, Indonesia (2013). p. 274-275. [in Bahasa

Indonesia].http://etd.repository.ugm.ac.id/index.php?mod=penelitian_detail\&sub=Pen elitianDetail\&act=view\&typ=html\&buku_id=66269\&obyek_id=4

28. C. Setijadi, ISEAS: Perspective, 73:1-12(2017). https://www.iseas.edu.sg/images/pdf/ISEAS_Perspective_2017_73.pdf

29. E.P. Hendro, Jurnal Sabda, 8:34-42(2013). [in Bahasa Indonesia]. https://ejournal.undip.ac.id/index.php/sabda/article/view/13228/10013

30. E. Susanti, Sosial Budaya, 12,1:56-67(2015). [in Bahasa Indonesia]. http://ejournal.uin-suska.ac.id/index.php/SosialBudaya/article/view/1931

31. M. Arif, Sosio Didaktika, 1,1:52-63(2014). [in Bahasa Indonesia]. http://journal.uinjkt.ac.id/index.php/SOSIO-FITK/article/view/1212

32. M. Kodiran. Jurnal Ketahanan Nasional, 17,1:19-30(2012). [in Bahasa Indonesia]. https://jurnal.ugm.ac.id/jkn/article/view/22672 